\title{
HŐKAMERA ALKALMAZÁSA KONTAKTKORRÓZIÓ VIZSGÁLATÁRA
}

\section{THERMOGRAPHIC CAMERA APPLICATION FOR GALVANIC CORROSION DETECTION}

\author{
Haraszti Ferenc \\ Óbudai Egyetem, Bánki Donát Gépész és Biztonságtechnikai Mérnöki Kar, Biztonságtudományi Doktori \\ Iskola , Budapest, Magyarország, haraszti.ferenc@bgk.uni-obuda.hu
}

\begin{abstract}
A part of the electric connections has a corrosion aptitude. It can find a galvanic corrosion process danger in case of the contact between different electron potential metals. This process impairs the connection resistance and mechanical properties. The conduction parameters decrease in some under power parts because the heat increasing. This heat effect can be unperceived. By the way of thermographic camera experiments can be discovered this irregularity on time. In this work present this investigation and the emerging problems.
\end{abstract}

Keywords: galvanic corrosion, thermographic camera, current, balckbody, emission.

\section{Összefoglalás}

A villamos csatlakozások egy részének működése korrózióval jár. Kontaktkorróziós folyamat veszélyt jelenthet, eltérő elektronpotenciálú fémek közötti érintkezés esetén. Ez a folyamat károsítja a csatlakozási ellenállást és a mechanikai tulajdonságokat. A vezetési paraméterek kisebbek a teljesítmény részeken, mert hőhatás alakulhat ki. Ez a hőhatás sokáig nem érzékelhető. Termokamerás kísérletek útján ez a rendellenesség időben felfedezhető. Ebben a munkában kerül bemutatásra a vizsgálati lehetőség és a felmerülő problémák.

Kulcsszavak: kontaktkorrózió, hőkamera, áramerősség, fekete test, emisszió.

\section{Bevezetés}

A villamosipar energiaátviteli, áramkapcsolati módszerei közé tartoznak a sínes, csavaros kötőelemek. A megfelelő vezetési és szilárdsági tényezők miatt, gyakori az acél-réz-alumínium kontaktus kialakítása. Ez viszont hosszú távon kontaktkorróziós problémákat generálhat. A különböző fémek eltérő elektródpotenciál értékei miatt ugyanis a kötőelemek helyielemként kezdenek el működni. A negatívabb fém ilyenkor oldatba megy és felületén korróziós folyamatok indulnak meg. Ez károsan befolyásolja az áramátvitelt a megnövekedett átmeneti ellenállás miatt. Jelentősen romlik a kötés szilárdsága is az elkorrodált fém veszteség miatt.

\section{Vizsgálatok elvi alapjai}

\subsection{Hőkamera alkalmazási lehetősége}

Modern korunkban nem élhetünk elektromos áram nélkül. A fém összeköttetés csatlakozási élettartamának meghatározása nagyon nehéz, mert a korróziós jelenség nehezen közelíthető számítással. Az elektromos érintkezésből adódó káresemények nagy problémákat okozhatnak az ipari és a magánéletben is. Az elektromos eszközök élettartamának előrejelzése évszázadunk kihívása. A legegyszerübb vizsgálatok a vizuális ellenőrzés és a hőmérsékletmérés. A hőmérsékletmérés miatt, viszont áramtalanítani kell az adott kötést, ami üzemkimaradást okoz. A hő- 
mérsékletmérés nem egyszerű a hagyományos módszerek alkalmazásával, mert ebben a folyamatban kikapcsoljuk az áramot. Az áramellátás szüneteltetése az iparban és az otthonokban is károkat okozhat. A korszerű technológiai fejlődés eredményeként új eszközöket találhatunk a biztonságos és pontos hőmérsékletméréshez. Egyik ilyen eszköz a hőkamera a termográfia legfontosabb mérőeszköze. A nagysorozatban történő gyártás lehetővé teszi az egyre szélesebb körben való elterjedését. Villamos rendszereknél számos hibajelenség léphet fel, ami elsősorban a túláram okozta felmelegedés következménye. A fent említett korróziós hatásokon kívül gondot okozhat a menetzárlat, vezeték szakadás, a berendezés túlterhelése. Problémaforrás lehet még a nem megfelelő csatlakozási mechanika, kötéslazulás, különböző deformációk az érintkező felületeken. Termokamera használatával feltárható a hiba pontos helye. Hőtérképet készíthetünk a vizsgált berendezésről, melyet referenciaként alkalmazhatunk a későbbi ellenőrzések alkalmával. Üzemi hőmérsékleteket ellenőrizhetünk, megállapíthatjuk a szakszerű karbantartás minőségét. A termográfiai mérés segítségével, jóval a meghibásodás előtt képet kaphatunk a villamos rendszer állapotáról. Ezeknek a méréseknek igen nagy a költség hatékonysága, hiszen egy ma már olcsónak számító mérőberendezéssel nagymértékben lehet csökkenteni az állásidőt, katasztrófához vezető nagy anyagi veszteségekkel járó tűzeseteket lehet megelőzni.

\subsection{Hőkamera mérési elve}

Az infrasugárzáson alapuló hőmérséklet mérés, illetve hőkamerás mérési módszer a testek hősugárzó képességétől függ. Hőmérsékleti sugárzás az a folyamat, mely az anyag hőmozgása miatt elektromágneses hullámokat bocsát ki magából. Ennek az energiának a nagy része másik testre vetülve emittálódhat, vagy reflektálódhat továbbá transzmittálódhat. Ha a vizsgált testre érkező sugárzást a test maradék nélkül elnyeli, akkor abszolút fekete testről beszélhetünk. Ha teljes mértékben visszaverődik, akkor abszolút tükröződő testről, ha a testen teljes mértékben áthalad, akkor átlátszó anyagról van szó. A hősugárzásnak, mint elektromágneses hullám terjedésnek közvetítőközegre nincs szüksége. A hősugárzás alaptörvénye a Stefan-Boltzmann törvény (1).

$$
P=e \sigma A_{s} T^{4}
$$

ahol a T [K] a hőmérséklet,
P [J] a sugárzás teljesítménye ,

e [-] emisszió,

$\mathrm{A}_{\mathrm{s}}\left[\mathrm{m}^{2}\right]$ a felület nagysága, és

$\sigma=5,6710^{-8}\left[\mathrm{~J} / \mathrm{m}^{2} \mathrm{~K}^{4}\right]$ a Stefan-Boltzmann állandó.

Amennyiben e, As és $\sigma$ állandók az összefüggés egyszerüsíthető (2):

$$
P=\sigma \cdot T^{4}
$$

Ebben az összefüggésben a fekete test sugárzása T-hőmérsékleten az egységnyi területre és az egységnyi idő alatt arányos a $\mathrm{T}^{4}$-nel. Ideális esetben a fekete test képes felvenni és kibocsátani az összes hőenergiát. Ez csak egy modell. Különböző anyagok különböző energiát bocsátanak ki. A mérésnél a fekete testhez hasonló anyag pontos eredményt ad. A különböző anyagok esetében javítani kell az eredményt.

\section{Vizsgálatok}

\subsection{Kísérleti anyagok és előkészítésük}

Nagyon gyakori a réz és az acél villamos kötésekben való alkalmazása. A kontaktkorrózió jelenségének vizsgálata során létrehoztam egy laboratóriumi modellmérési rendszert. A vizsgálat előtt felületi tisztítást végeztem, majd korróziós terhelés (3\%-os sószórással 168 óra alatt, $40{ }^{\circ} \mathrm{C}$ hőmérsékleten) alatt határoztam meg az eredményeket. A kísérletben alkalmazott mintákat az 1-3. ábrák mutatják be.

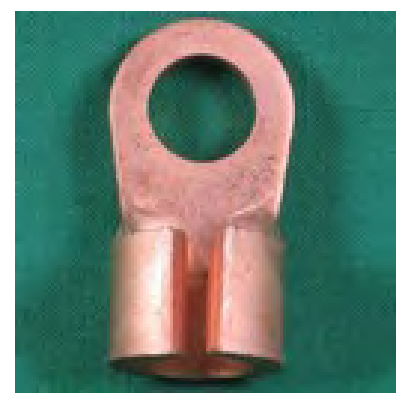

1. ábra. Réz saru

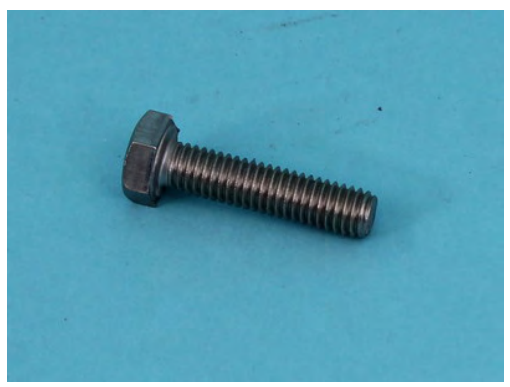

2. ábra. Acél csavar 


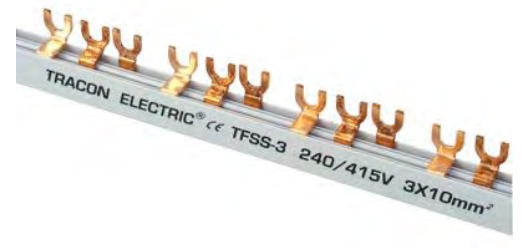

3. ábra. Soroló sín egy fázisú, max. 63 A

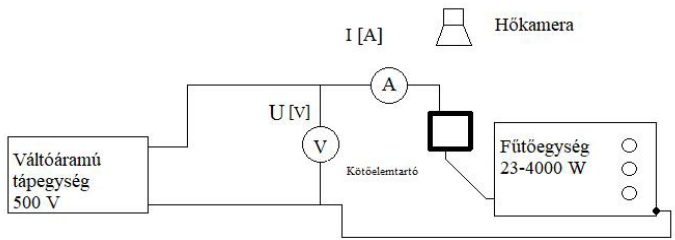

4. ábra. Mérés elvi összeállítási rajza

\subsection{Vizsgálati módszer}

A 4. ábra bemutatja a kísérleti elrendezést. A fütőberendezés különböző kapcsoló állásában a használt teljesítmény eltér. Az elektromos áram nagysága változik az előkészített kötésen, ahol mérhető hő keletkezik, mivel az ellenállás az elő-

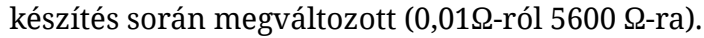
A termo kamera lehetővé teszi a biztonságos és pontos hőmérési folyamatot. Ebben a kísérletben a kötés hőmérsékletét a villamos áram változásának függvényében mértem.

\subsection{Mérési eredmények}

Az 1. táblázat mutatja azokat a kísérleti eredményeket, amelyek a mért hőmérséklet és az áram közötti összefüggést mutatják. A nagy sürűségű villamos energia hőt termel. A 3. egyenlet alapján feltételezhető a hőmérséklet és a teljesítmény közötti összefüggés. Az egyenlet, ahol $\mathrm{P}$ [W] a villamos teljesítmény, I [A] az elektromos áramerősség, U [V] a feszültség:

$P=U \cdot I$

1. táblázat. Mérési adatok

\begin{tabular}{|c|c|c|}
\hline Sorszám & Áramerősség [A] & Hőmérséklet [ ${ }^{\circ} \mathbf{C}$ ] \\
\hline 1 & 0 & 27,2 \\
\hline 2 & 0,08 & 27,4 \\
\hline 3 & 0,15 & 28,4 \\
\hline 4 & 3,9 & 44,3 \\
\hline 5 & 7,66 & 75 \\
\hline 6 & 11,58 & 125 \\
\hline
\end{tabular}

Az Ohm törvényt alkalmazva, ahol az ellenállás $\mathrm{R}[\Omega]$ a következő összefüggés adódik (4):

$$
P=R \cdot I^{2}
$$

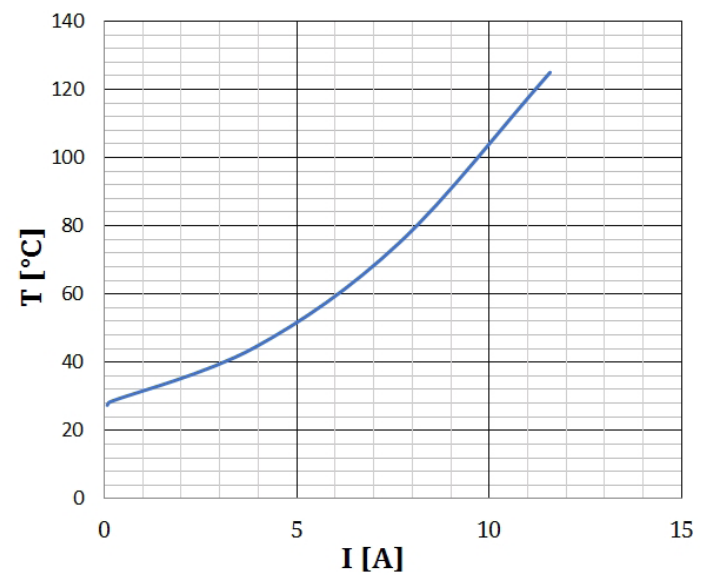

5. ábra. A hömérséklet és az áramerősség kapcsolata

Ebből az egyenletből látható, hogy kísérletben a villamos energia négyzetesen arányos a hőenergiával (5. ábra).

\section{Következtetések}

A kísérletek eredményeként kimondható, hogy a hipotézis, miszerint az áramerősség és a kötésben létrejövő hőmennyiség között kapcsolat van igazoltnak tekinthető.

A villamos kötés hőmérséklete változott a vizsgálati idő alatt. Ennek az eredménynek az alapján azt a következtetést vonhatjuk le, hogy az ipari (valós) alkalmazásokban ugyanazt a jelenséget észlelhetjük.

A kontaktkorrózió hatására a kötés ellenállása is megváltozik. A keletkező hő mérhető és ez hőkamerával jó közelítéssel és biztonságosan meghatározható. A következő ábrákon a villamos kötőelem hőkamera által készített képei láthatók (6-7. ábra).

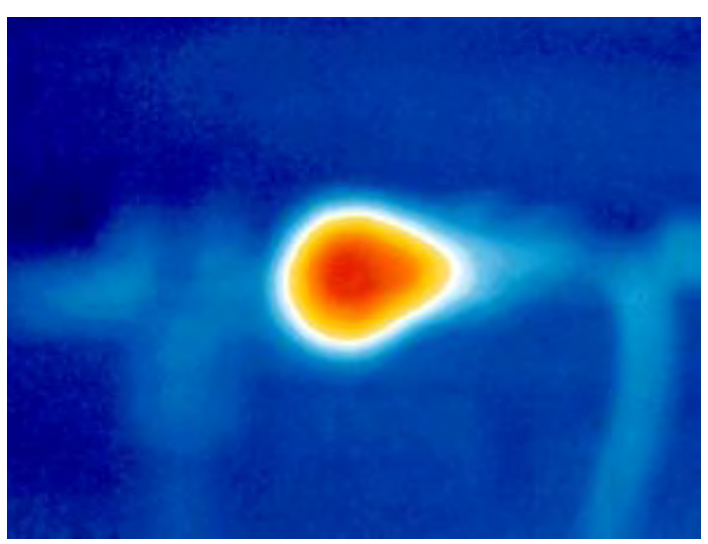

6. ábra. Kötés hőmérséklet $44,3{ }^{\circ} \mathrm{C}$ 


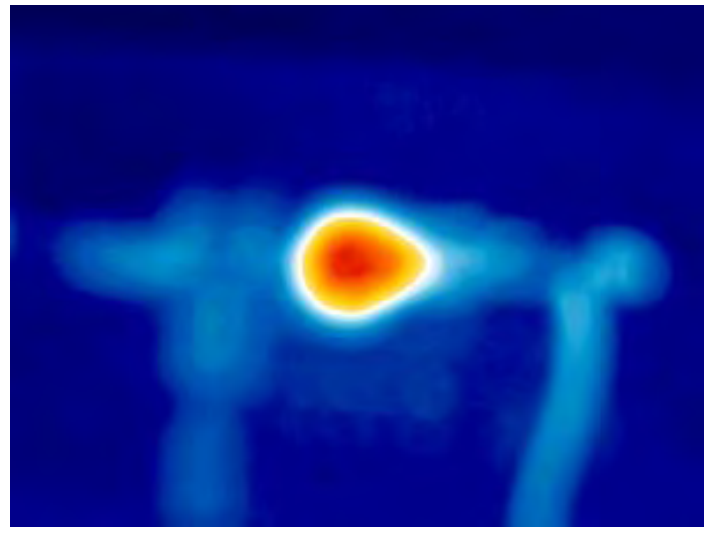

7. ábra. Kötés hőmérséklet $125^{\circ} \mathrm{C}$

\section{Szakirodalmi hivatkozások}

[1] Haraszti F.: The bases of corrosion's investigation. In: A XXI. Fiatal műszakiak tudományos ülésszak előadásai. Proceedings of the 21th international scientific conference of youngth engineers, Kolozsvár/Cluj, Románia, Müszaki Tudományos Közlemények 5. (2016) 185-188. https://eda.eme.ro/handle/10598/29058
[2] Haraszti F.: Corrosion investigation of steel smaples. In: A XXI. Fiatal müszakiak tudományos ülésszak előadásai. Proceedings of the 21th international scientific conference of youngth engineers, Kolozsvár/Cluj, Románia, Müszaki Tudományos Közlemények 5. (2016) 189-192.

https://eda.eme.ro/handle/10598/29057

[3] Kovács-C. T., Völgyi B., Sikari-Nágl I.: Galvanic corrosion behavirour testing in case of aluminum and steel couple. In: Fiatal müszakiak tudományos ülésszaka XVIII., Kolozsvár/Cluj, Románia, Múszaki Tudományos Füzetek 2013. 201-204. https://eda.eme.ro/handle/10598/26880

[4] Wellons M.: The Stefan-Boltzmann Law. Physics Department, The College of Wooster, Wooster, Ohio 44691, USA, May 9, 2007.

[5] Kittel C., Kroemer H.: Thermal Physics (W. H. Freeman and Company, 1980) ASTM Standard Practice in A 262 for Detecting Susceptibility to Intergranular Corrosion in Austenitic Stainless Steels.

[6] www.termokamera.hu, www.globalfocus.hu

[7] Budó Á.: Kísérleti Fizika II. Tankönyvkiadó, Budapest, 1971. 